\title{
How does imperviousness develop and affect runoff generation in an urbanizing watershed?
}

\author{
GERALD KREBS, ULLA-MAIJA RIMPILÄINEN AND OUTI SALMINEN
}

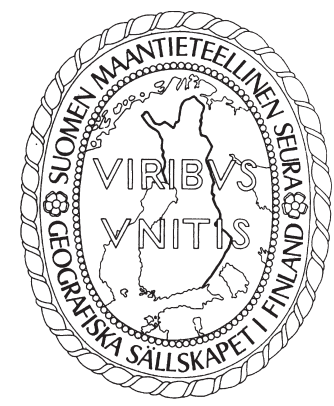

Krebs, Gerald, Ulla-Maija Rimpiläinen \& Outi Salminen (2013). How does imperviousness develop and affect runoff generation in an urbanizing watershed? Fennia 191: 2, pp. 143-159. ISSN 1798-5617.

Imperviousness associated with urbanization remains one of the biggest challenges in sustainable urban design. The replacement of forests, marshlands, buffers, and wetlands with impervious surfaces, strongly influences hydrological processes in urbanizing areas. This study analyzes the contribution of four constructed surfaces types - roofs, yards, roads, and an international airport - to surface runoff within a $21 \mathrm{~km}^{2}$ watershed, and presents the development over five decades (1977-2030). The land-cover model, used to assess watershed imperviousness in 2030, utilizes coefficients between impervious areas generating surface runoff and the floor area, developed during the study. The conducted imperviousness analysis allows the evaluation of land-use development impacts on the stream network, and the identification of hydrologically active areas for urban planning and stormwater management. Research reveals the importance of yard imperviousness related to suburban residential housing for stormwater runoff generation, and the impacts of transport-related imperviousness on stormwater runoff.

Keywords: urban planning, land-use, imperviousness, stormwater runoff, imperviousness-components

Gerald Krebs, Aalto University School of Engineering, P.O.Box 15300, FI-00076 Aalto, Finland. E-mail: gerald.krebs@aalto.fi

Ulla-Maija Rimpiläinen, City of Vantaa, Kielotie 28, 01300 Vantaa, Finland and Aalto University School of Arts, P.O.Box 11300, FI-00076 Aalto, Finland. E-mail: ulla-maija.rimpilainen@vantaa.fi

Outi Salminen, University of Helsinki, Department of Forest Sciences, P.O.Box 27, Fl-00014 University of Helsinki, Finland. E-mail: outi.m.salminen@helsinki.fi

\section{Introduction}

In the year 2000, $70.8 \%$ of the European population lived in urban conditions and the percentage will increase to $77.4 \%$ in 2030 . Development in Finland follows the pattern of Western Europe; $82.2 \%$ of the population lived in urban areas in the year 2000 and about $86.2 \%$ will in 2030 (United Nations 2012). Urban development is associated with the construction of building facilities and infrastructure to inhabit enlarging future population, leading to higher levels of impervious land cover. The fraction of impervious cover within the gross watershed area is defined as the degree of imperviousness. Grimm et al. (2008) note that imperviousness is among the most important land cover modifications affecting stream condition in urban areas.
Land cover modifications alter the watershed hydrology and affect both, surface and subsurface water bodies. These modifications are seen in a decrease of forested stream buffer and wetland areas that provide capacity for retention and purification (Brabec et al. 2002). The impacts on water bodies include increased stress on stream hydrology, channel morphology, water quality, and stream ecology imposed by changes in stormwater quality and quantity (Brabec 2009), and changes in the eco-hydrological diversity of watersheds (Booth \& Jackson 1997). Further impacts include reduced infiltration, increased surface runoff, higher peak discharge in streams, shorter travel time, and more severe pollutant loads influencing both surface water quantity 
and quality (Lee \& Heaney 2003; Beighley et al. 2009). Stream water quality is deteriorating as direct urban runoff transports pollutants from contaminated surfaces (such as roads, parking lots, roofs, urban parks, and recreational areas) into aquatic systems, without adequate filtration (Bannerman et al. 1993; Ruth 2003). Besides surface waters, imperviousness also affects groundwater bodies. Impacts include problems in water supply and reduced low flow volumes in streams, caused by a reduction of the groundwater recharge rate (Arnold \& Gibbons 1996; Haase 2009).

The impacts of land cover modifications on water bodies can be assessed using the degree of imperviousness. It is an important indicator of stream health (Schueler 1994), and can be used as an index to address complex urban environmental issues (Arnold \& Gibbons 1996). Even though threshold values are always controversial (Brabec 2009), Schueler (1994) concludes in a review of several stream degradation studies that they produce a fairly consistent result - stream degradation already occurs at levels of low imperviousness $(10 \%-20 \%)$, and becomes unavoidable at 20\%-30\% impervious land cover (Arnold \& Gibbons 1996). Haase (2009) reported in a long-term water balance study for the city of Leipzig that direct runoff doubles at a degree of imperviousness around $20 \%$ compared to unsurfaced land. Furthermore, evapotranspiration rates clearly declined and groundwater recharge slightly reduced at the same level of imperviousness.

Imperviousness can be subdivided into a natural and an artificial component. Natural imperviousness considers areas with elevated surface runoff due to varying soil types, surface condition and vegetation, whereas artificial or manmade imperviousness refers to areas where changes in stormwater runoff quality and quantity are caused by human activities. This manmade imperviousness can be subdivided into three components: 1) roof surfaces, 2) road surfaces, and 3) impervious surfaces on yards including terraces, parking areas, and driveways from different land-use types existing in the watershed. Additionally, in this study, the development of the imperviousness generated by the Helsinki-Vantaa airport was assessed separately as a fourth component due to the uniqueness of this land-use type. Common land-use assessments relate the percent- age of imperviousness with a land-use type. However, there are no standardized methods for deriving these relationships; therefore, there is typically a high variation in the fraction of impervious area within the same landuse type (Canters et al. 2006). Direct methods of land-use assessment, including ground surveys, interpretation of large scale aerial photographs or satellite imagery (Beighley et al. 2009) were developed to overcome these inaccuracies. In practice, the direct methods are time consuming and costly, and can usually only be applied in small watersheds (Canters et al. 2006).

The objective of this research was to analyze the contribution of different impervious surface components and their properties, both, to imperviousness and stormwater runoff generation within the watershed of the Kylmäoja stream in Southern Finland. This analysis consists of an assessment of the past land-use development between 1977 and 2007 and an imperviousness prediction for 2030. The forecast of imperviousness is difficult and implies numerous assumptions, such as future building and population density, building heights, and the distribution of residential and commercial areas. In this study, the land-use and population data from 1977-2007 was analysed to assess the watershed imperviousness development. The same data was used to develop coefficients between floor-, roof-, and yard areas. These coefficients were then used to create a connection between future building densities, floor areas, and impervious surfaces in 2030. The hydrological impacts of the imperviousness development were evaluated adopting a categorization scheme from Schueler (1994) for ultimate imperviousness, and runoff calculation using the rational method. Stormwater runoff in this study refers to runoff generated on constructed impervious surfaces in urban areas. The stormwater runoff does not include runoff generated in natural impervious areas outside the constructed areas. The analyzed components included the common elements of urban development (Schueler 2000), such as rooftops, yard areas, and roads from various land-use types (residential, commercial, and industrial areas), as well as the Helsinki-Vantaa airport. Three mitigation scenarios are presented and their efficiency evaluated for the study catchment. 


\section{Methods and materials}

\section{Site description}

The research site was the Kylmäoja watershed (Fig. 1) located north of Helsinki in Finland, and shared between the city of Vantaa and the municipality of Tuusula. Both, Vantaa and Tuusula are part of the Greater Helsinki Metropolitan Region with about one million inhabitants (Population Register Centre 2011). The watershed area is $20.83 \mathrm{~km}^{2}$, with about $75 \%$ or $15.71 \mathrm{~km}^{2}$ located in the city of Vantaa, and $25 \%$ or $5.12 \mathrm{~km}^{2}$ in the municipality of Tuusula (Krebs 2009). The watershed is dominated by suburban residential land-use with scattered small industrial areas. Furthermore, parts of the Helsinki-Vantaa airport are located within the watershed (Fig. 1). The urban areas (Tikkurila and Ruskeasanta) located in the southern part of the watershed, and the surfaces of the Helsinki-Vantaa airport (opened for traffic in 1952, FINAVIA 2012) in the northeast, were mostly constructed before the first year (1977) of the land-use assessment conducted in this study. The northern areas in Vantaa (residential areas such as Ilola in the beginning of the 1990s) and Tuusula (focus on industrial development since the 1990s) were developed more recently, and are still subject to major construction activities (Vantaan kaupunki 2008; Tuusulan kunta 2009). The selected watershed represents a typical sub-urban watershed in Southern Finland, with a strong development of residential housing on the one hand and fast industrial development due to good traffic connections on the other hand.

The stream network consists of four branches - eastern, central and western headwaters join-

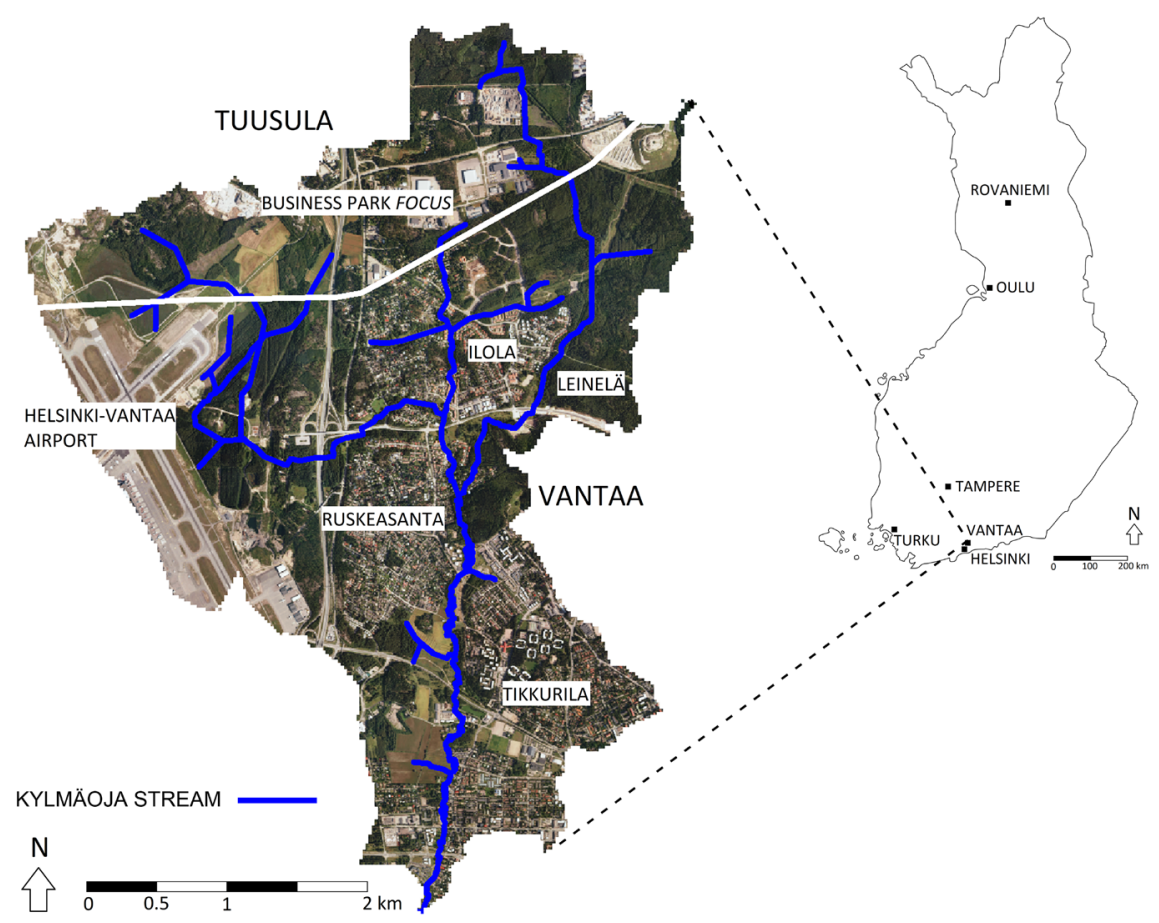

Fig. 1. Aerial image of the Kylmäoja watershed, located in Vantaa and Tuusula, Southern Finland. The map shows the most urbanized areas in the southern watershed area (Tikkurila and Ruskeasanta), residential areas like Ilola in the centre of the watershed area, the Helsinki-Vantaa airport in the west, and important future developments like Leinelä (Vantaa) and the Business Park FOCUS (Tuusula). The stream network of Kylmäoja and the border between Vantaa and Tuusula are also shown (Modified, original Vantaan kaupunki). 


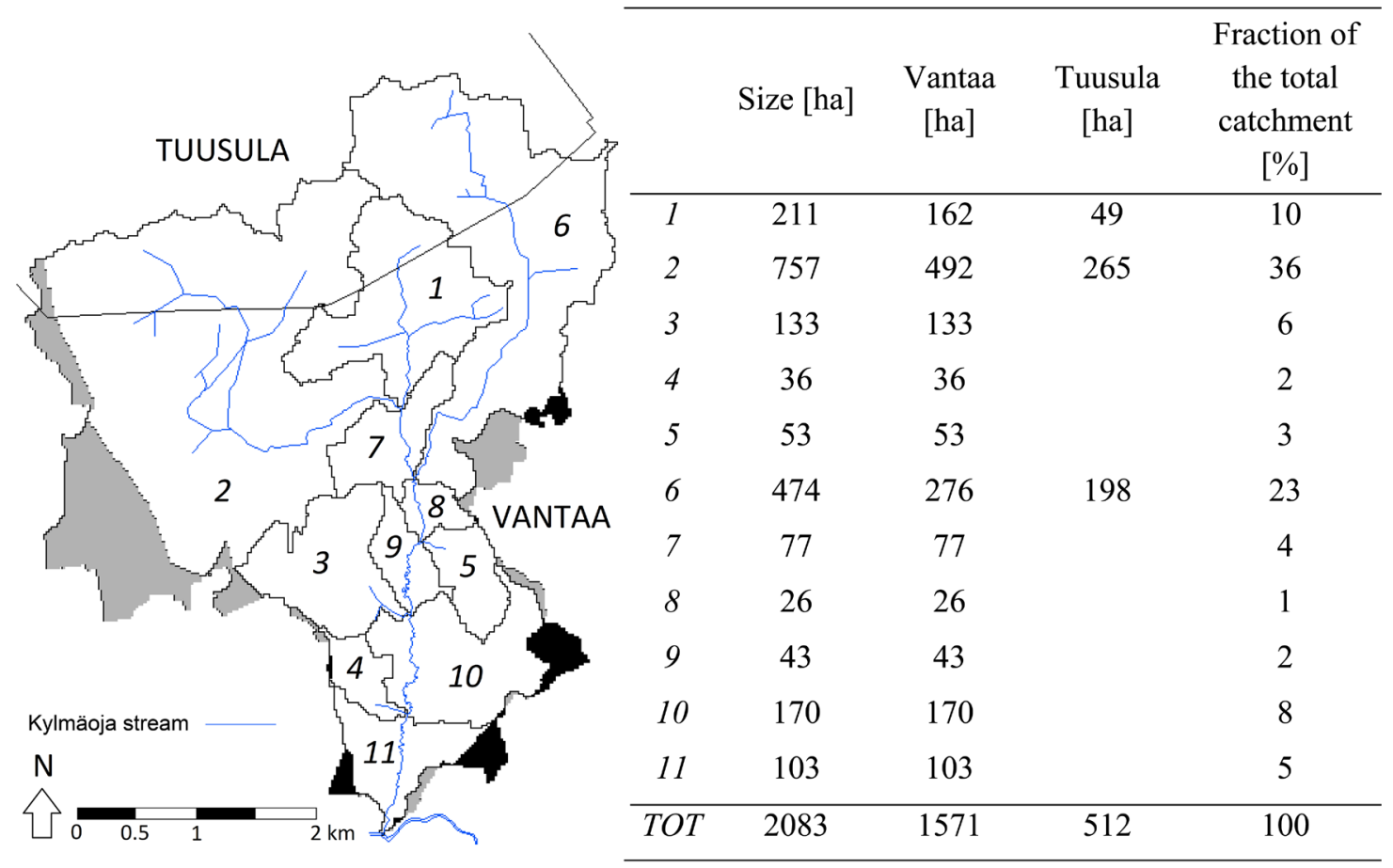

Fig. 2. The eleven subcatchments defined during this work. The subcatchments 1, 2, and 6 are transboundary subcatchments shared by Tuusula and Vantaa. The effects of the conventional sewer pipe network on the catchment are also shown. Grey areas belong to the topographical catchment but are drained into nearby streams; black areas are not part of the topographical watershed but are piped into the Kylmäoja stream. The spatial properties of the watershed and the subcatchments are presented in the table on the right hand side (size, area located in Vantaa and Tuusula, and fraction of the entire watershed).

ing the main branch. The entire watershed was divided into eleven subcatchments according to the stream network, with three subcatchments being transboundary, shared by the city of Vantaa and the municipality of Tuusula (Fig. 2 ). The division into subcatchments can guide city planners in Vantaa and Tuusula to set focuses and objectives for urban planning and stormwater management by defining specific areas of importance within the catchment area.

\section{Land-use analysis}

The watershed and stream network were delineated with the software Geoinformatica (Jolma 2007) using the D8 method (Fairfield \& Leymarie 1991) on a 25 m-raster digital elevation model (DEM). The actual stream network location was determined with aerial images produced in the year 2007; differences between the actual and mod- elled stream network were corrected accordingly. The catchment and subcatchment borders were modified to correspond with the existing stormwater sewer network. The conducted delineation was based on data from the year 2007 and thus represents the catchment borders and stream network at this time point. The results of the delineation were used for the entire time period assessed in the analysis.

Spatial analysis focused on the distribution of impervious surfaces of different land-use types (such as residential, commercial, and industrial areas) within the watershed to assess the development of ultimate imperviousness $(U I)$ within the Kylmäoja watershed between 1977 and 2030; therefore, the development of the roof area, the road surface area, the yard imperviousness, and the area of the Helsinki-Vantaa airport was investigated over the study period. Both, the size and the quality of these surfaces were evaluated based on 
housing and road datasets in Vantaa, aerial photography, and historical maps.

The land-use assessment was conducted for a period of five decades from 1977 to 2007 , and further on to 2030. The analysis from 1977 until 2007 is based on existing construction. Roof and impervious yard areas were derived from aerial photography; and floor areas and plot-ratios (maximum permitted floor area divided by the plot area) were compiled from building permit archives. The forecast for 2030 is based on zoning plans, providing information about plot-ratios to define building density in the future.

Forecast of imperviousness requires a link between impervious surface area development and parameters of urban growth, such as future building or population density. Few methodologies are available to predict imperviousness (creating a link between imperviousness and population density or land-use, respectively) and generally have shortcomings concerning small areas (Reilly et al. 2004). Therefore, in this study, coefficients were chosen to link the floor area of a building (used in urban planning) with the building roof- and yard area (relevant for runoff) to predict imperviousness development in small urban scale. This approach allows for consideration of local peculiarities in suburban dwellings, as the coefficients were developed for the specific study catchment.

Coefficients between the stormwater relevant variables (rooftops and yard imperviousness) and zoning variables (such as the floor and living area) were developed for the period 1977-2007 (Eq. $1-3)$. The coefficients were developed for each subcatchment, each observed year, and each building type defined by the city of Vantaa. Consideration of different areas, time periods and building types accounted for dwelling developments, and changes in architectural style within the study area.

The developed coefficients in Vantaa differed from the coefficients in Tuusula, due to the variation in available data. The coefficients developed in this work are the relationship between roof and floor areas for Vantaa (used also for Tuusula)

$$
C_{R \text { Vantaa }}=\frac{A_{R}}{A_{F}}
$$

the relationship between impervious yard and floor areas for Vantaa

$$
C_{Y \text { Vantaa }}=\frac{A_{Y}}{A_{F}}
$$

and the relationship between impervious yard and roof areas for Tuusula

$$
C_{Y \text { Tuusula }}=\frac{A_{Y}}{A_{R}}
$$

where $A_{R}\left[m^{2}\right]$ is the roof area, $A_{F}\left[m^{2}\right]$ is the floor area, and $A_{Y}\left[m^{2}\right]$ is the yard area.

The above coefficients were derived using spatial data for the time period before 2007. As there was no data on floor area for existing buildings in Tuusula for 1977-2007 available, the coefficient derived for subcatchments with similar structure in Vantaa $\left(C_{R \text { Vantaa }}\right)$ was used also for Tuusula subcatchments. Furthermore, for the same reason, the impervious yard area was put in relation to the roof area, obtained directly from aerial images, instead of the floor area $\left(\mathrm{C}_{\mathrm{Y} \text { Tuusula }}\right)$. While the selected approach hinders the direct comparison of developed coefficients between the cities, it does not affect the prediction of impervious yard areas in Tuusula for 2030 and the comparison of imperviousness development between the cities.

These coefficients were implemented to derive impervious surfaces from the expected floor area in 2030. The future development of floor area (based on plot-ratios) was adopted from the projections made by the city of Vantaa, as the building density within the watershed in 2030 is expected to be less than the maximum allowed density. Three different site types exist in the current development plans: undeveloped areas, fill-in sites, and sites where the plot-ratio utilization can be optimized. Undeveloped areas have defined densities in the plans but the plot-ratios are not yet defined. Thus, this type of development involves the largest uncertainties in future floor area forecasts. On the other hand, the time of realization in the currently undeveloped areas is rather clearly defined. Fill-in sites are empty plots within already developed areas, for which the plot-ratio and hence maximum floor area defined. Estimates for the future floor area are rather certain, as due to the high real estate prices in the capital area of Finland (Suomen virallinen tilasto 2010), these sites can be assumed to be used to the maximum plot-ratio defined. Sites for plot-ratio optimization are sites where the existing buildings have a smaller floor area than would be allowed by the authorities. Whereas it can be assumed that the maximum plot-ratio will be utilized at some future point (driven by real estate prices), the actual time of realization involves uncertainties, as it is often driven by ownership changes. 


\section{Ultimate imperviousness}

Ultimate imperviousness $(U I)$ is the sum of the imperviousness generated by the categories assessed in the land-use analysis. Those were the road and roof areas, impervious yard areas, and the Helsinki-Vantaa airport. UI considers constructed imperviousness and does not include naturally impervious surfaces such as rock formations. The effects of land-use changes on the Kylmäoja stream were evaluated using the determined ultimate imperviousness $(U I)$ as an indicator of stream health (Schueler 1994). UI is used both as an indicator and as a guideline criterion for stormwater management practices and objectives. UI categorization follows the threshold values suggested by Schueler (1994), defined as sensitive streams (watershed imperviousness 0-10\%), impacted streams (watershed imperviousness 11-25\%), and nonsupporting streams (watershed imperviousness $>25 \%$ ). No such classification exists for river basins in Finland, whereas the Schueler classification is based on a large number (18) of catchmentstream relationship studies carried out across the USA for various catchment types and scales. Stream condition in Schueler's review (1994) considered stream parameters such as channel stability, water quality, and stream diversity as well as catchment parameters, such as land-use controls, development rights, and the condition of buffer zones.

\section{Runoff generation analysis}

Runoff generation calculation considered different surface materials and adopted the values for runoff coefficients from German (ATV-DVWK-REGELWERK 2000) and Finnish (RIL 2004) manuals. Runoff generation used the rational method and runoff coefficients characterizing different surface types (Eq. 4).

$$
Q=\sum_{i=1}^{n} A_{i} q c_{i}
$$

where $Q\left[\mathrm{I} \mathrm{s}^{-1}\right]$ is the discharge, $A_{i}[\mathrm{ha}]$ is the area of contributing surface types, $q\left[\mathrm{~s} \mathrm{~s}^{-1} \mathrm{ha}^{-1}\right]$ is the rainfall intensity, $C_{i}[-]$ is the runoff coefficient of contributing surface types, and $i[-]$ is the number of different surface types within the watershed.

The runoff generation analysis focused on changes in the peak of a design runoff event following modifications in catchment imperviousness. The design peak runoff is calculated using
Eq. (4), and it is induced by a 15 min design rainfall intensity that occurs once in 50 years. The design rainfall intensity is adopted from Kilpeläinen (2006), who summarized precipitation statistics from Helsinki-Kaisaniemi between 1951 and 2000, and reported that a 15 min rain event with a return period of 50 years generates a precipitation of $255\left[\mathrm{l} \mathrm{s}^{-1} \mathrm{ha}^{-1}\right]$. The selected rainfall intensity was used for all simulations conducted in this study.

Roof areas were assigned with a runoff coefficient of 0.9 (Kibler 1982; ATV-DVWK-REGELWERK 2000; RIL 2004). Road surfaces made of asphalt (almost $98 \%$ of the roads within the KyImäoja watershed were asphalt-paved in 2007) were assigned with a runoff coefficient of 0.95 and a value of 0.60 characterized the minor share of public gravel covered roads (ATV-DVWK-REGELWERK 2000). Yard surfaces are more variable and differ depending on the building type. Aerial images and in-situ study showed that in low density residential areas around half of the yard surfaces were covered with asphalt and half with gravel, described by a runoff coefficient of 0.63 . In medium dense residential development areas the asphalt-gravel ratio was found to be $80-20 \%$, described by a runoff coefficient of 0.82 . Yard areas associated with apartment blocks, industrial buildings, and other service facilities had mainly asphalt covered yard areas with an assigned runoff coefficient of 0.95 (ibid.). Asphalt areas associated with the Helsinki-Vantaa airport were assigned the same runoff coefficient (0.95) as the bituminous road surfaces.

Stormwater runoff was simulated for the analyzed land-use in the Kylmäoja watershed for the years 1977, 1992, and 2007. Furthermore, the stormwater runoff was estimated for the year 2030 in four scenarios to evaluate impacts of current plans as well as the potential of three mitigation approaches. All four scenarios for 2030 considered construction development within the watershed between 2008 and 2030. For scenario 1, roof and impervious yard area of new buildings were calculated using the developed relationships $\left(C_{R}\right.$ Vantaa' $\mathrm{C}_{\text {Y Vantaa' }}$ and $\mathrm{C}_{\mathrm{Y} \text { Tuusula }}$.

The U.S. Environmental Protection Agency (2006) concluded in a report that higher-density development creates less runoff, and impacts the watershed less than low-density development at all scales for a given development. Generated runoff from a building depends on the contributing roof area; therefore, a higher structure - with several floor levels - has a smaller footprint than a 
building with less floor levels, and thus, generates less runoff due to the smaller roof area. Thus, for scenario 2, an increase in building height - the floor area being unaffected - was suggested and therefore used a lower coefficient $C_{R V \text { antaa }}$.

Scenario 3 evaluated the effects of more pervious surface material use for yard areas, simulated by a runoff coefficient variation. Depending on the land-use type, the proportion of impervious materials used on yards was reduced by $20 \%$ (instead of asphalt, the utilisation of gravel, wide tiles, alternative pavers or vegetated areas was supported) to evaluate the potential reduction in runoff for 2030. While for scenario 1, the yard runoff coefficient for detached houses and low-rise housing areas was set to 0.63 the reduction of impervious materials by $20 \%$ ( $80 \%$ of the area pervious materials) results in a runoff coefficient of 0.43 . For row houses the share of asphalt was reduced to $50 \%$, with a runoff coefficient of 0.63 (0.82 in scenario 1). The share of asphalt in yard areas for offices and apartment blocks was reduced to $80 \%$ (from $100 \%$ in scenario 1 ), resulting in a runoff coefficient of 0.82 .

Scenario 4 assumed that $10 \%$ of buildings in the Kylmäoja watershed would have an extensive green roof installed by the year 2030. While scenarios 1-3 were calculated for the study watershed, scenario 4 uses estimates based on a green roof runoff reduction study conducted in Brussels (Mentens et al. 2006). They used regression equations and concluded a potential runoff reduction of $2.7 \%$ for the city of Brussels for the assumption of $10 \%$ of the roofs receiving an extensive green roof.

\section{Results and discussion}

\section{Relationships of area types}

The coefficients between the constructed roof area and the floor area $\left(C_{R \text { Vantaa }}\right)$, derived for buildings constructed between 1992 and 2007 are shown in Table 1. The coefficients are presented for four categories of building types: 1) Low-rise residential (detached and row housing), 2) high-rise residential area (apartment blocks), 3) service areas (meant for public and private facilities such as schools, daycare but also road administration and water supply), and 4) workplace areas (including office buildings as well as industrial production).
$C_{R \text { Vantaa }}$ for low-rise residential areas varied from 0.69 to 0.92 (i.e., a floor area of $100 \mathrm{~m}^{2}$ is associated with roof area of 69-92 $\mathrm{m}^{2}$ ). The corresponding coefficients in high-rise residential areas found in five subcatchments are lower and range from 0.37 to 0.52 . The coefficients for service areas were found to be equal to the ratios for high-rise residential areas. The coefficients $(0.80-0.81)$ for workplace areas show little variation, except for office areas found in subcatchment 2 (0.62) (Table 1).

Both coefficients concerning yard imperviousness $\left(C_{Y \text { Vantaa }}\right.$ (Eq. 2) and $C_{Y \text { Tuusula }}$ (Eq. 3)) show far greater variation within and between the categories. In low-rise residential areas in Vantaa the coefficients found range from 0.33 to 0.95 , i.e., an impervious yard area of 33-95 $\mathrm{m}^{2}$ was related to $100 \mathrm{~m}^{2}$ of floor area. Apartment block coefficients in Vantaa range from 0.52 to 0.88 and service areas have an impervious yard area of 52-69 $\mathrm{m}^{2}$ connected to $100 \mathrm{~m}^{2}$ of floor area. The largest variation in coefficients was found for industrial production and maintenance areas, where values in Vantaa reach from 0.62 to 2.52. Large yard imperviousness connected to low floor area was found for retail parks, logistics and transportation companies, all three having maximum two-storeybuildings and hence little floor area compared to roof area and large asphalt areas for parking, maneuvering, and exhibition (Table 1). While the yard imperviousness coefficients for Tuusula had to be related to the roof area rather than the floor area (as in Vantaa) they follow a similar pattern. The coefficient found for low-density residential areas was with 0.78 significantly lower than found for industrial areas in Tuusula (1.72-2.15). Both apartment blocks and service areas do not exist in the Tuusula areas of the watershed.

\section{Watershed Imperviousness}

UI was used to assess the impacts of land-use changes on the Kylmäoja stream. $U I$ is presented as a percentage for each of the eleven subcatchments as well as for the entire Kylmäoja watershed for the years 1977, 1992, 2007, and 2030 (Fig. 3). The classification thresholds are based on the study review conducted by Schueler (1994). This classification scheme was applied in the Kylmäoja watershed, because there are no water quality data available from the stream to directly compare imperviousness analysis results to actual stream health. Even though the effects of imperviousness 
Table 1. $C_{R \text { Vantaa' }} C_{Y_{\text {Vantaa }}}$ and $C_{Y \text { Tuusula }}$ for the eleven subcatchments defined for the construction period 1992-2007.

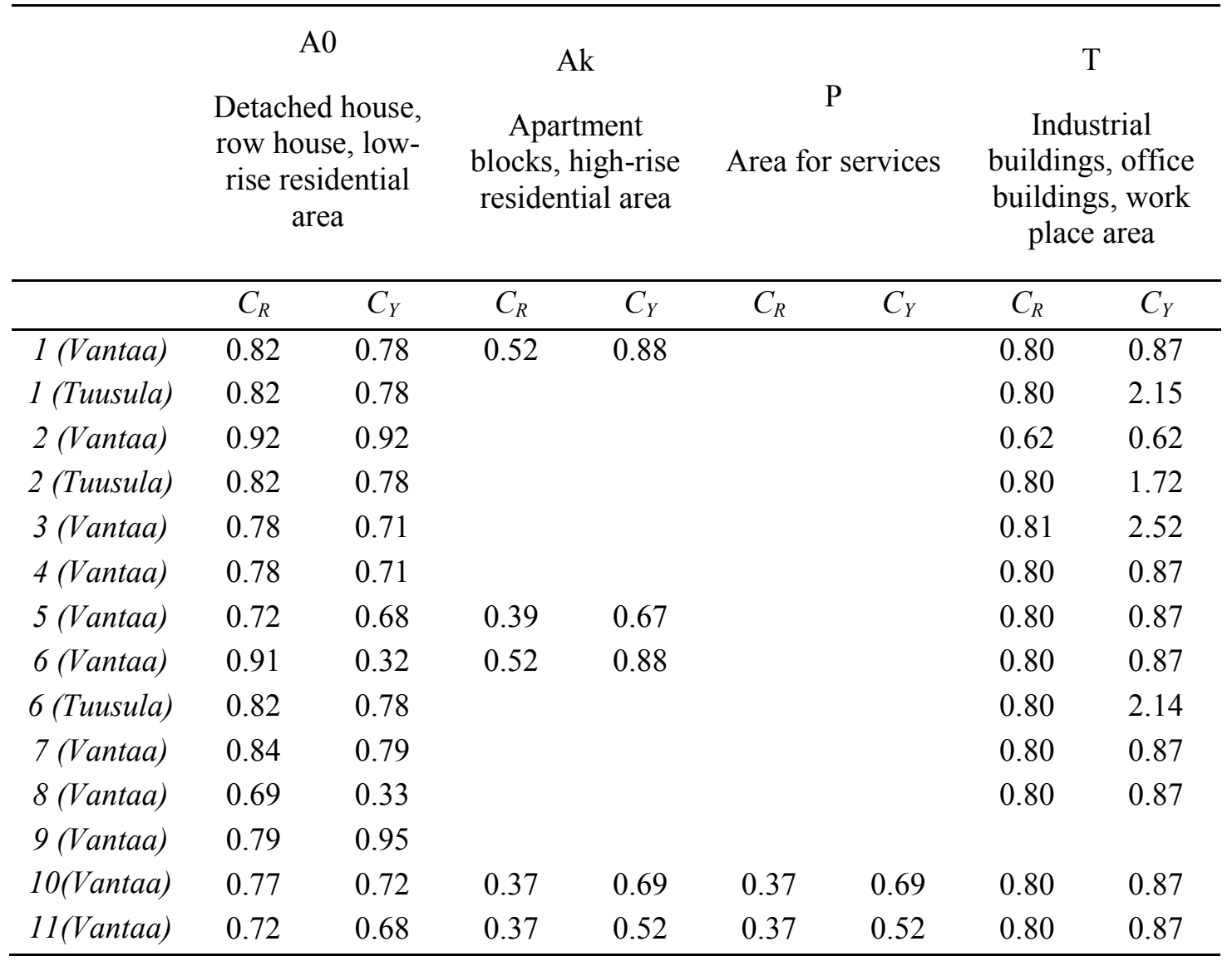

on stream health are affected by site and climate conditions, Schueler's classification (1994) is based on a wide range of studies (18) conducted under varying climate conditions and thus allows conclusions on stream condition and urban development impacts on streams. Furthermore, it provides guidelines for urban planning concerning the future development. At the beginning year of analysis in 1977, the highest degree of imperviousness was found for the subcatchments in southern Vantaa and around the Helsinki-Vantaa airport. According to Schueler's (1994) categorization, the identified imperviousness implies a reduction in channel stability, water quality, and stream diversity. The resource objective for this stream condition is shifted from protection to maintenance to achieve a better ecological condition. The six remaining subcatchments had imper- viousness rates below the threshold value of $10 \%$, defining these sections of Kylmäoja as healthy with stable channels and beds, good water quality, and stream diversity. The airport subcatchment showed little change with an increase of $2 \%$ from 1977 to 1992 whereas residential development effects can be seen in the imperviousness of the subcatchments 7 and 9. Two subcatchments remained below the threshold of $10 \%$ in 1992, while the two most urban subcatchments 10 and 11 exceeded the threshold of $25 \%$. This degree of imperviousness results in poor channel stability, water quality, and biodiversity, and moves the resource objectives from maintenance of the affected section to minimization of pollutant loads reaching downstream waters. In 2007 five subcatchments exceeded the threshold of $25 \%$ located within the southern areas of the Kylmäoja watershed. Clear 


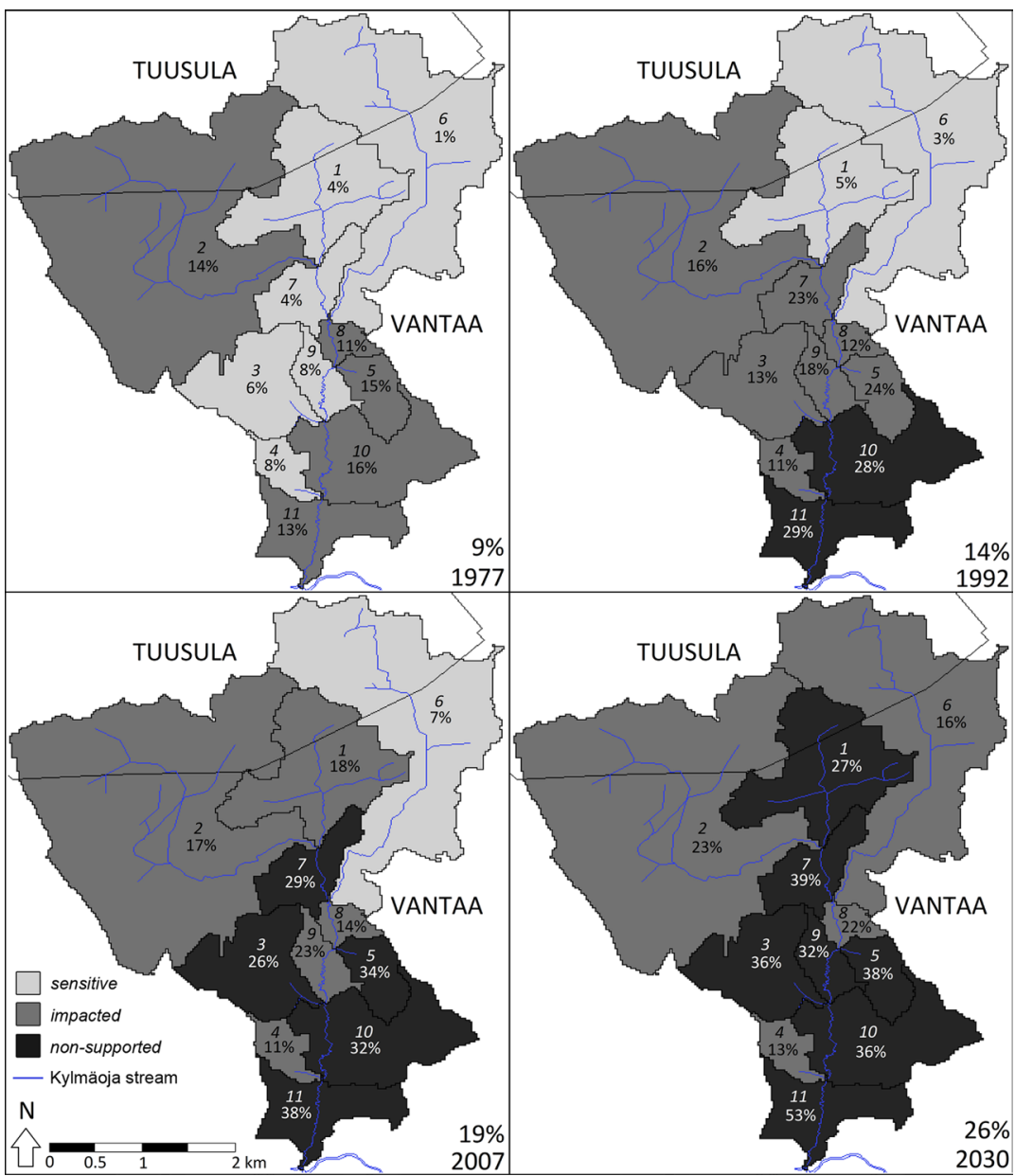

Fig. 3. Imperviousness in the watershed 1977-2030. Whereas in 1977 six stream sections (and the whole stream) were sensitive and five sections impacted, in 2007 only one section was sensitive, five impacted, and five non-supporting. In 2030 four sections will be impacted and seven non-supporting (and the whole stream). No part of Kylmäoja will be sensitive anymore. Imperviousness of the entire watershed is shown above the observation year.

increase is also seen in the earlier rather undeveloped subcatchments 1 and 6, which drain into the central and eastern headwaters of Kylmäoja. The forecast for 2030 expects seven subcatchments to exceed the threshold value for a non-supporting stream, and five are classified to be impacted. No subcatchment within the Kylmäoja catchment will be sensitive anymore, in other words all sections and the entire stream will be exposed to degradation at some level.

UI for the entire Kylmäoja watershed shows a permanent growth due to land-cover change from $9 \%$ in 1977 to $19 \%$ in 2007. In 2030 UI is ex- pected to reach $26 \%$. While the link between future building density and future impervious surfaces was developed based on catchment data from 1977 to 2007, the forecast is based on future projections and involves uncertainties concerning the actual building density in the watershed by 2030. These uncertainties are induced by factors such as the political and economic environment both within the communities sharing parts of the Kylmäoja watershed as also neighbouring cities and municipalities. Besides the level of watershed imperviousness, another important indicator for the effects of land-use on the quality of streams is 
the distance of impervious areas from the aquatic system (Brabec 2009). This criterion was not investigated during this work, but would be an important indicator of stream health for further studies on this watershed.

The EU Water Framework Directive (European Parliament and Council 2000) defines the good ecological status for water bodies as the target objective, and demands water resources management at river basin scale. As watershed borders are determined by topographical conditions, the watershed scale approach requires cooperation of authorities (reaching from regional to international scale) in transboundary basins. UI was therefore evaluated separately for the three transboundary subcatchments of the Kylmäoja watershed. While the subcatchment areas in Vantaa are mainly dominated by suburban residential developments, areas in Tuusula are in focus of industrial development, also due to residential building restraints north of the Helsinki-Vantaa airport.

Besides the Vantaa part of subcatchment 2, due to the presence of the Helsinki-Vantaa airport since 1952 (FINAVIA 2012), the transboundary subcatchments had little degree of imperviousness in 1977, ranging between 0-5\%. In subcatchment 2 , the degree of imperviousness will be slightly higher within the Tuusula areas (25\%) than within the Vantaa areas (23\%) in 2030. In subcatchment 6 , imperviousness in Tuusula will yield at $21 \%$, whereas in Vantaa it will be $12 \%$. The largest difference in imperviousness development was found for subcatchment 1. Already in 2007 the imperviousness in Tuusula was 30\% compared to $14 \%$ within the residential areas on the Vantaa side of the border. This difference will enlarge further in 2030 , with $43 \%$ of imperviousness in Tuusula and $22 \%$ of imperviousness in Vantaa by then (Fig. 4).

The high degree of imperviousness within the Tuusula part of the watershed is especially influential on stream health, as the areas drain into the headwaters of Kylmäoja. Consequently, all physical, biological and chemical impacts are effective for the entire stream length. Furthermore in subcatchment 6 , the city of Vantaa has established a nature reserve of 11.3 ha (Kylmäojan korpi) in

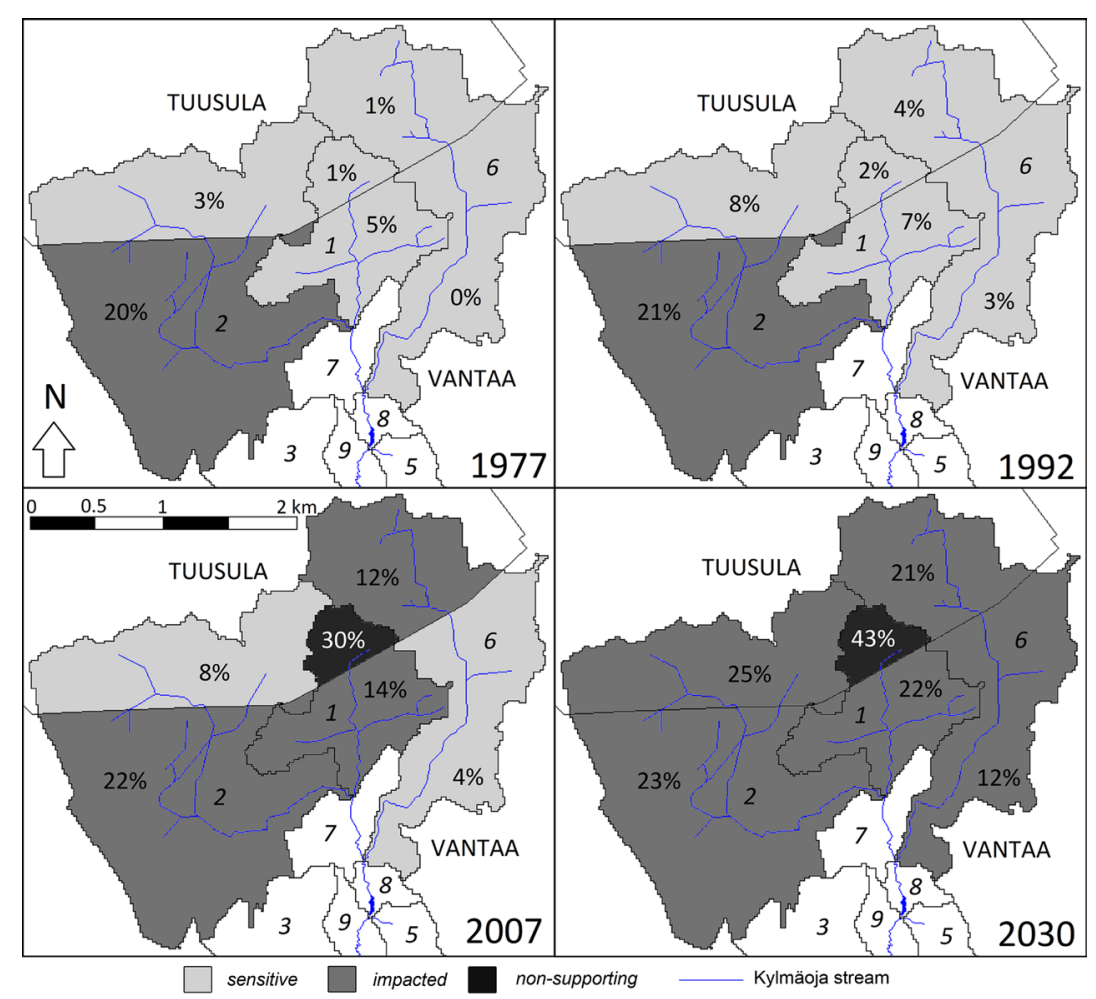

Fig. 4. The maps show the development of imperviousness for the three transboundary subcatchments 1977-2030. 
2002 (Rantalainen 2004) south of the municipal border, receiving the increasing stormwater runoff from industrial areas in Kulomäki located just north of the border. The results also show that cooperation between municipalities concerning stormwater management is not sufficient yet and has to be improved to meet the requirements of the EU Water Framework Directive.

Both the network of the Kylmäoja stream and the catchment and subcatchments were delineated based solely on data from the year 2007. Comparisons of the results with aerial images taken prior the year 2007 showed that the stream network and the total catchment boundaries were not affected by the development of new areas within the Kylmäoja watershed. However, the possible impact of new developments 1977-2007 on subcatchment boundaries prior 2007 possibly affects the calculated degree of imperviousness due to extensions of the stormwater sewer network.

\section{Stormwater runoff generation on impervious areas - Scenario 1}

The stormwater runoff was calculated using the rational formula (Eq. 4) with source areas derived during the spatial analysis, runoff coefficients and a 15 min rain with an intensity of $255\left[\mathrm{I} \mathrm{s}^{-1} \mathrm{ha}^{-1}\right]$. Between 1977 and 2007, the lowest increase in generated stormwater runoff was found in subcatchment 2, which includes the main parts of the Helsinki-Vantaa airport, and in subcatchment 4, which is located south of the airport. As stated earlier Helsinki-Vantaa airport opened for traffic in 1952, before the first year of the spatial analysis and has little expanded within the Kylmäoja catchment since then. The presence of the airport leads to a high stormwater runoff generation already in 1977, but construction restraints around the airport have limited increase of imperviousness during the study period. The largest increase in runoff generation between 1977 and 2007 occurred in subcatchment 6 where the value increased more than tenfold from 1977 to 2007. The subcatchment located in northeast of Kylmäoja was mostly undeveloped until 1992, when residential construction started in the Vantaa part of the subcatchment and industrial development increased in Tuusula (Fig. 5).

Based on current urban development plans in Tuusula and Vantaa, stormwater runoff generation increase is likely to reach the largest value within subcatchment 6 , mainly due to the business park FOCUS (Tuusulan kunta 2009) and the residential development plans in Leinelä in Vantaa (Vantaan kaupunki 2008). The reported generated runoff uses a rainfall intensity of $255\left[\mathrm{l} \mathrm{s}^{-1} \mathrm{ha}^{-1}\right]$ suggested by Kilpeläinen (2006). The possible changes in rainfall intensity due to climate change and the effect on the generated runoff have not been investigated in this study. However, the conducted detailed analysis of impervious surfaces in the watershed allows the application of different rainfall intensities or frequency storms for future studies.

Cheng and Wang (2002) reported an increase of $27 \%$ in peak discharge associated with an imperviousness growth from $4.78 \%$ to $11.03 \%$ for a $204 \mathrm{~km}^{2}$ watershed in Taiwan. Kim et al. (2011) assessed the impacts of urbanization on runoff using SWAT-SWMM simulations on the white rock creek watershed in Texas, US, and concluded an increase in surface runoff by $12 \%$ when doubling the watershed imperviousness. Yu et al. (2003) used a distributed rainfall-runoff model for a $35 \mathrm{~km}^{2}$ watershed in Taiwan. They found that the water balance fraction of surface runoff increased from $10 \%$ to $17 \%$ associated with a watershed imperviousness increase from $20 \%$ to $64 \%$. In our study, the predicted increase in surface runoff caused by an imperviousness growth from $19 \%$ to $26 \%$ was found to be $41 \%$. The stronger increase in runoff for the Kylmäoja catchment might be explained by the larger area of directly connected impervious surfaces present at a higher degree of imperviousness. While the selected approach using the rational method allows the assessment of the runoff generation from impervious surfaces, an assessment of the water balance and watershed surface runoff requires the inclusion of pervious catchment areas. This approach could be conducted in a future study based on the conducted land-use analysis. Furthermore, similar hydrologic assessments have been conducted in earlier studies (Jang et al. 2007; Haase 2009; Spencer et al. 2009).

The role of four different runoff source areas was investigated: roofs, roads, yards and the Helsinki-Vantaa airport. For the years 1977, 1992, 2007 and 2030 the generated stormwater runoff was calculated by source area to identify their influence on runoff and to show the potential of the source area for applying corrective measures in urban planning (Fig. 6). Runoff generated on natural impervious areas within the 

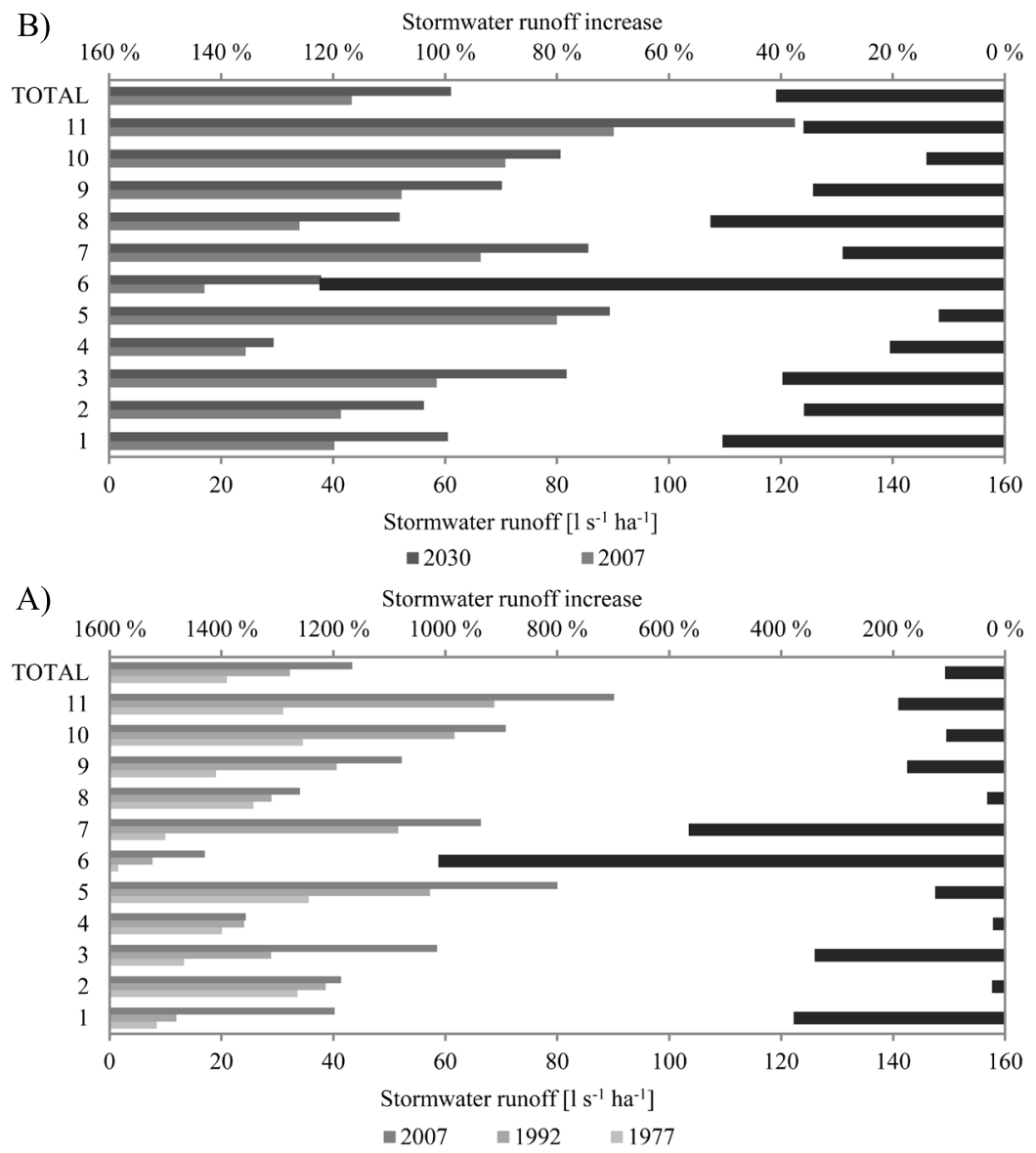

Fig. 5. Stormwater runoff development and increase for 1977-2007 (A) and 2007-2030 (B) for the 11 subcatchments and the KyImäoja watershed in Scenario 1.

watershed (such as open rock formations) was not considered in the conducted runoff analysis. While these areas do contribute to the overall runoff in the watershed, their contribution does not affect the development of runoff generated due to urban construction, as this construction usually replaces pervious areas (such as fields or forests) rather than open rock formations. Thus, in this study, the contribution of natural imperviousness to watershed runoff was assumed to remain constant over time and discarded in the presented contribution of analysed imperviousness components.

In 1977, more than half of the stormwater runoff in the Kylmäoja watershed was generated on the bituminous runways and associated areas of the Helsinki-Vantaa airport. The contribution of roof, yard and road surfaces to stormwater runoff in 1977 ranged between $15 \%$ and $18 \%$. The total traffic-related area (TTA) contribution, considering stormwater runoff from the airport, yard areas, and road network, accounted for about $84 \%$ of stormwater runoff within the Kylmäoja watershed in 1977. As the Helsinki-Vantaa airport is a unique source of stormwater runoff, the traffic related runoff excluding the airport areas was also investigated, to allow for comparison with other suburban watersheds. This suburban traffic-related area (STA) describes the contribution of traffic-related areas, if only roofs, yards, and roads are taken into account for runoff calculation, and thus represent $100 \%$ of the stormwater runoff in the watershed. In $1977,77 \%$ of the stormwater runoff within the watershed was generated on STA. 


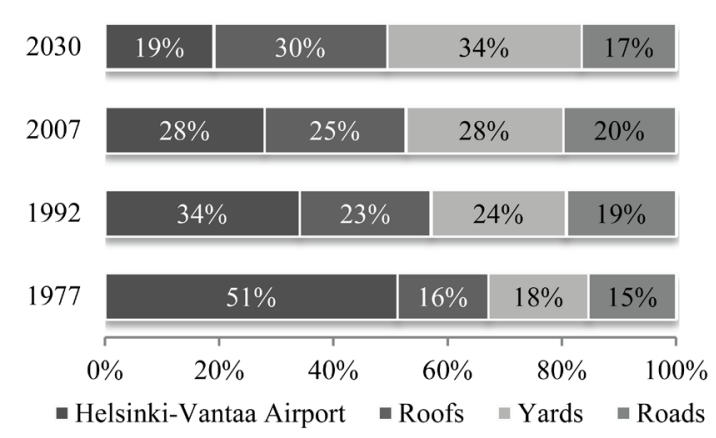

Fig. 6. Contribution of the four analyzed components to stormwater runoff in the Kylmäoja watershed 1977-2030.

From 1977-1992 a decreasing influence of the Helsinki-Vantaa airport on stormwater runoff and an increasing impact of roof- and yard surfaces can be seen. Consequently, also the influence of TTA and STA decrease to $77 \%$ and $65 \%$, respectively. Observation in 2007 indicates further reduction of the relative influence of the Helsinki-Vantaa airport generating $28 \%$ of stormwater runoff in the Kylmäoja watershed. Stormwater runoff from yard areas equals the impact of the airport, whereas roofs generate slightly less runoff.

The forecast for 2030 indicates that the most important source of stormwater runoff generation will be the yard areas accumulating $34 \%$. Roofs will account for $30 \%$, the Helsinki-Vantaa airport for $19 \%$ and road surfaces will have the smallest share (17\%). TTA will generate $70 \%$ and STA $63 \%$ of the stormwater runoff within the Kylmäoja watershed in 2030.

In Tuusula, the extent and ongoing growth of impervious yard surface, caused by the high degree of industrialisation, is especially influential. The impervious yard area in Tuusula alone will account for $14 \%$ of runoff generation within the watershed in 2030, twice as much as roofs (7\%) and even almost four times more than roads (3\%). Besides the extension of these areas, the industrial focus in Tuusula also implies that practically $100 \%$ of these yard areas are asphalt covered and thus highly impervious. Detached houses, as an example, were found to have typically $50 \%$ of their driveways covered with asphalt and 50\% with gravel surface.
Traffic related areas (STA) in a medium density suburban area ranges from $63 \%$ to even $70 \%$ (City of Olympia 1994), depending on the layout of parking facilities and streets. STA within the Kylmäoja catchment in 1977 was higher $(77 \%)$ than measured in Olympia in 1994. Over time the value decreased to $65 \%$ in 2007 and $63 \%$ in 2030, within the range of the City of Olympia (1994) study. The reduction is explained by residential areas, which were more densely built after their first development and which had the roof areas increasing faster than the road areas.

\section{Approaches for improvements - Scenario $\mathbf{2}$ higher structures reduce the roof area}

The lowest coefficient between roof area and floor area for apartment blocks and office buildings was found to be 0.37 and 0.40 , respectively. Both values derive from buildings constructed between 1993 and 2007. The value of 0.4 describes a building with three to four floors. For scenario 2, the coefficient was reduced to 0.20 , thus every apartment- and office building to be constructed 2008-2030 has six floors (instead of three). The reduction potential (Scenario 1 vs. Scenario 2) naturally depends on development plans within the watershed as only apartment blocks and office buildings are influenced. Furthermore, the potential is the largest in areas, where the expected increase in stormwater runoff is the largest. For the subcatchments 6 and 8 , a reduction potential of $16 \%$ and $12 \%$ was found. The reduction equals $6\left[\mathrm{I} \mathrm{s}^{-1} \mathrm{ha}^{-1}\right]$ for both subcatchments. The reduction for the whole KyImäoja watershed was found to be $4\left[\mathrm{I} \mathrm{s}^{-1} \mathrm{ha}^{-1}\right]$ or $7 \%$ (Fig. 7). These results confirm conclusions drawn by the US Environmental Protection Agency (2006) suggesting that high-density development generates less runoff.

Even though the attempt to support high and therefore slim structures for these building types offers a potential for reduction of stormwater runoff, it is uncertain how large the effect is in reality. The question, how the yard areas belonging to structures are designed, is crucial. The reduction of roofage is only then a reasonable approach, if the reduced impervious area is not compensated by construction of parking lots, clearing the positive effect. 

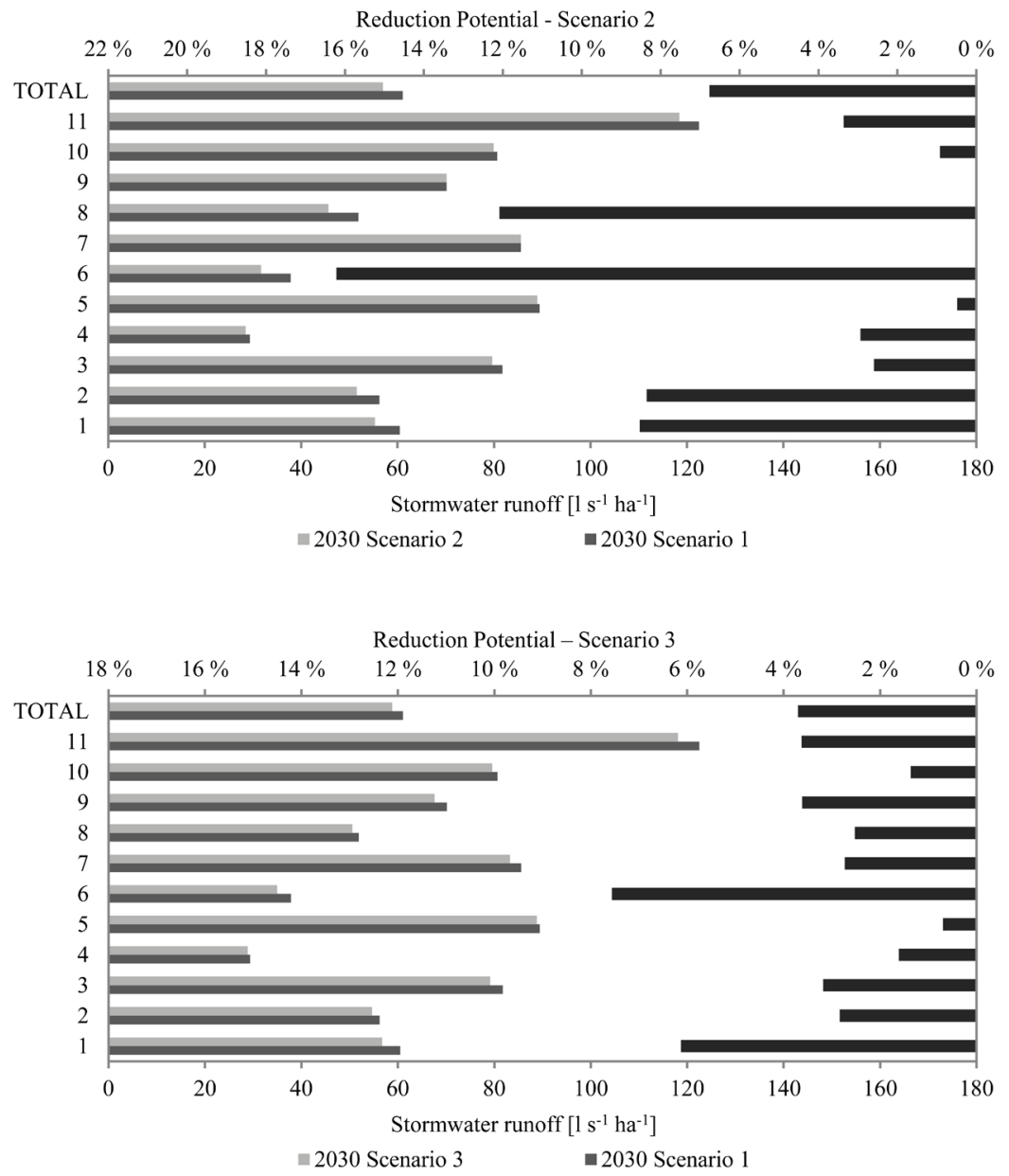

Fig. 7. The peak runoff generated from impervious areas in the Kylmäoja watershed calculated for the 11 subcatchments and the Kylmäoja watershed in 2030 (Scenario 1 and 2) and the runoff reduction potential of Scenario 2 .

Fig. 8. The peak runoff generated from impervious areas in the Kylmäoja watershed calculated for the 11 subcatchments and the KyImäoja watershed in 2030 (Scenario 1 and 3) and the runoff reduction potential of Scenario 3.

\section{Approaches for improvements - Scenario 3 perforation of yards}

As stated earlier the yard areas contribute significantly to the total stormwater runoff. This influence suggests that the perforation of yard areas through the use of less impervious materials could be a feasible approach for stormwater runoff mitigation. Depending on the land-use type, the proportion of impervious materials used on yards was reduced by $20 \%$ to evaluate the potential reduction in runoff for 2030. All changes are, as conducted for the higher structure approach, applied for buildings to be constructed 2008-2030. The reduction potentials (Scenario 1 vs. Scenario
3) for the subcatchments 6 and 1 were found to be $8 \%$ and $6 \%$, respectively. The reduction equals $3\left[\mathrm{l} \mathrm{s}^{-1} \mathrm{ha}^{-1}\right]$ for both subcatchments. The reduction for the whole Kylmäoja watershed was found to be $2\left[\mathrm{I} \mathrm{s}^{-1} \mathrm{ha}^{-1}\right]$ or $4 \%$ (Fig. $8)$.

In contrast to the attempt of supporting higher structures, the reduction of impervious yard area is also applicable to existing yards, even though the changes in yard surface types were only applied for buildings to be constructed, to allow for direct comparison. Furthermore, the variation of yard area imperviousness is effective for all building types in the catchment - reaching from a one-family house to an apartment block - and does not 
depend on building height. Stone (2004) argues that a reduction of impervious cover through driveway perforation would have 'substantial benefits for the region' when applied in Madison, USA. Even though his suggested increase of infiltration (from zero to $80 \%$ ) for driveways is far more progressive than applied in this study (plus 20\% infiltration), the importance of yards for zoning practices is evident.

\section{Approaches for improvements - Scenario 4 green roofs}

The increase of green areas in cities does not only have a positive eco-hydrological effect, but enhances life quality in urban areas. Unfortunately, due to limited space and high land prices, the recreation and preservation of green areas in urban circumstances are often regarded to be very expensive if not impossible (Mentens et al. 2006). Roofs will account for almost one third of stormwater runoff in the Kylmäoja watershed in 2030; therefore, the mitigation of these areas is worth evaluating. Mentens et al. (2006) conducted an intensive literature review to investigate the actual effect of green roofs on yearly runoff in Brussels and found that extensive roof greening - a substrate layer between 30 and $140 \mathrm{~mm}$ in depth - on $10 \%$ of the roofs would reduce the annual runoff in the urban area by $2.7 \%$. To assess the effect of green roofs on stormwater runoff generation in Kylmäoja, we follow this suggestion and assume that $10 \%$ of the buildings in the watershed receive an extensive green roof by 2030, reducing the stormwater roof runoff by approximately $38 \%$. The investigation showed that $30 \%$ or almost one third of the generated runoff in 2030 will derive from roofs. The reduction of stormwater runoff by $38 \%$, applied for $10 \%$ of the rooftops in the watershed, results in a total reduction of $3.8 \%$ for the runoff generated from roofage. The stormwater runoff in the whole Kylmäoja watershed can be reduced by about $1.2 \%$. As mentioned, neither seasonal changes nor climate differences between the area in Belgium (Mentens et al. 2006) and Finland were considered, but the estimation shows the potential for runoff reduction using green roofs.

\section{Conclusions}

This study showed that the land-use changes within the Kylmäoja watershed have been rapid until the present day and will be also until the target year of this study, 2030. Based on the reported relationships between land-use and stormwater runoff, approaches for reduction of runoff peaks were evaluated. The attempt to support construction of higher buildings, thus having less roofage, was estimated to clearly reduce stormwater runoff. Reduction potential for the Kylmäoja watershed was found to be $7 \%$ for the Kylmäoja catchment and up to $16 \%$ for individual subcatchments. However, this tool is not effective without implementation of best stormwater management practices in the saved yard areas. If the reduction of roof area is compensated by increased parking places, the positive effect is diminished. The impact of yard areas on stormwater generation and hence the stream health became obvious. The contribution of impervious yard areas to stormwater runoff generation is higher than the contribution of the actual associated building roofs. Therefore it is important to closely investigate the runoff processes and potential mitigation measures in yard areas. The attempt to reduce asphalt surfaces on yard areas seems to be the easiest mitigation approach applicable in the Kylmäoja type of an urban area. In the proposed mitigation scheme the yard areas of detached houses contained no asphalt, maximum $50 \%$ of the row house yard areas were asphalt covered, and apartment blocks, office buildings and industrial facilities had less than $80 \%$ asphalt covered yard areas. These changes were only applied for newly constructed sites, and as such the estimate proved to be less effective than the reduction of roof area in newly constructed buildings with a reduction potential of $4 \%$ for the Kylmäoja watershed and up to $8 \%$ for the subcatchments. Nevertheless, the reduction of impervious yard surfaces is, compared to the reduction of roof area, applicable for both new and existing buildings and related with low costs. Recognizing that $34 \%$ of the accumulated stormwater runoff in Kylmäoja will derive from impervious yard areas, the runoff mitigation potential of those areas is of major importance to reduce the degrading effects of developed land on the Kylmäoja stream. The approach of introduction and support of green roofs in the watershed showed an estimated reduction potential of stormwater runoff of about $1.2 \%$, when $10 \%$ of the roofs in the catchment area were assumed to 
have an extensive green roof. Even though the use of extensive green roofs results in less stormwater runoff reduction than the reduction of roof area and yard perforation, the potential of the approach with $30 \%$ of stormwater runoff deriving from roof areas is existing.

\section{ACKNOWLEDGEMENTS}

The authors want to thank Prof. Harri Koivusalo for his comments on the manuscript. Furthermore, we wish to thank Prof. Ari Jolma, Prof. Riku Vahala, and Prof. Pertti Vakkilainen for their support and valuable advices during the conducted research. The personnel of the City of Vantaa and the municipality of Tuusula were very helpful in providing data and giving an insight to processes in urban planning and stormwater management. Funding for this research was provided by the City of Vantaa, the STORMWATER project (grant A30116), the HYDROSYS project (grant 224416, DG INF$\mathrm{SO})$, and Maa- ja vesitekniikan tuki Foundation.

\section{REFERENCES}

Arnold Jr CL \& Gibbons CJ 1996. Impervious surface coverage: The emergence of a key environmental indicator. Journal of the American Planning Association 62: 2, 243-258. http://dx.doi.org/10.1080 $\% 2 F 01944369608975688$.

ATV-DWMK-M 153 (2000) 2000. Handlungsempfehlungen zum Umgang mit Regenwasser, Arbeitsgruppe 1.4.3 "Regenwasserbehandlung". ISBN 3-927729-85-X (in German).

Bannerman RT, Owens DW, Dodds RB \& Hornewer NJ 1993. Sources of pollutants in Wisconsin stormwater. Water Science and Technology 28: $3-5,241-259$.

Beighley E, Kargar M \& HeY 2009. Effects of impervious area estimation methods on simulated peak discharges. Journal of Hydrologic Engineering 14: 4, 388-398.

http://dx.doi.org/10.1061\%2F\%28ASCE\%2910840699\%282009\%2914\%3A4\%28388\%29.

Booth DB \& Jackson CR 1997. Urbanization of aquatic systems: Degradation thresholds, stormwater detection, and the limits of mitigation. Journal of the American Water Resources Association 33: 5, 1077-1090. http://dx.doi.org/10.1111\%2Fj.1752-1688.1997. tb04126.x.

Brabec E 2009. Imperviousness and land-use policy: Toward an effective approach to watershed planning.
Journal of Hydrologic Engineering 14: 4, 425-433. http://dx.doi.org/10.1061\%2F\%28ASCE\%2910840699\%282009\%2914\%3A4\%28425\%29.

Brabec E, Schulte S \& Richards PL 2002. Impervious surfaces and water quality: A review of current literature and its implications for watershed planning. Journal of Planning Literature 16: 4, 500-514. http:// dx.doi.org/10.1177\%2F088541202400903563.

Canters F, Chormanski J, Van de Voorde T \& Batelaan O 2006. Effects of different methods for estimating impervious surface cover on runoff estimation on catchment level. Proceedings of the 7th International Symposium on Spatial Accuracy Assessment in Natural Resources and Environmental Sciences, 5-7 July 2006, Lisboa, Instituto Geográfico Português, eds. M. Caetano \& M. Painho, July 5-7, pp. 557.

Cheng S \& Wang R 2002. An approach for evaluating the hydrological effects of urbanization and its application. Hydrological Processes 16: 7, 1403-1418. http://dx.doi.org/10.1002\%2Fhyp.350.

City of Olympia 1994. Impervious surface reduction study: Technical and policy analysis - Final report. Public Works Department, Olympia, Washington.

European Parliament and Council 2000. Directive 2000/60/EC of the European Parliament and of the Council of 23 October 2000 establishing a framework for Community action in the field of water policy.

Fairfield J \& Leymarie P 1991. Drainage networks from grid digital elevation models. Water Resources Research 1:27, 709-717. http://dx.doi.org/10.1029\%2F90WR02658.

FINAVIA 2012. History of Helsinki Airport. <https://m. helsinki-vantaa.fi/en/helsinki-airport/in-brief/history/> 2.9.2013.

Grimm NB, Faeth SH, Golubiewski NE, Redman CL, Wu J, Bai X \& Briggs JM 2008. Global change and the ecology of cities. Science 319: 5864, 756-760. http://dx.doi.org/10.1126\%2Fscience.1150195.

Haase D 2009. Effects of urbanisation on the water balance - A long-term trajectory. Environmental Impact Assessment Review 29: 4, 211-219. http:// dx.doi.org/10.1016\%2Fj.eiar.2009.01.002.

Jang S, Cho M, Yoon J, Yoon Y, Kim S, Kim G, Kim L \& Aksoy H 2007. Using SWMM as a tool for hydrologic impact assessment. Desalination 212: 1-3, 344-356.

http://dx.doi.org/10.1016\%2Fj.desal.2007.05.005.

Jolma A 2007. Geoinformatica: a modeling platform built on FOSS. In Swayne DA \& Hrebicek J (eds). Proceedings of the 6th international symposium on environmental software systems (ISESS 2007), 22-25 May, Prague.

Kibler DF 1982. Urban stormwater hydrology. Water resources monograph Vol. 7. American Geophysical Union, Washington, DC.

Kilpeläinen T 2006. Kesäsateiden ilmastolliset piirteet Helsingin Kaisaniemessä 1951-2000. Thesis (MSc). University of Helsinki (in Finnish). 
Kim NW, Won YS, Lee J, Lee JE \& Jeong J 2011. Hydrological impacts of urban imperviousness in white rock creek watershed. Transactions of the ASABE 54: 5, 1759-1771.

Krebs G 2009. Development of land-use within the urbanizing Kylmäoja catchment. Thesis (MSc). Helsinki University of Technology.

Lee JG \& Heaney JP 2003. Estimation of urban imperviousness and its impacts on storm water systems. Journal of Water Resources Planning and Management 129: 5, 419-426.

http://dx.doi.org/10.1061\%2F\%28ASCE\%2907339496\%282003\%29129\%3A5\%28419\%29.

Mentens J, Raes D \& Hermy M 2006. Green roofs as a tool for solving the rainwater runoff problem in the urbanized 21st century? Landscape and Urban Planning 77: 3, 217-226. http://dx.doi. org/10.1016\%2Fj.landurbplan.2005.02.010.

Population Register Centre 2011. Kuntien asukasluvut aakkosjärjestyksessä 2011. <http://vrk.fi/default. aspx?docid $=4258 \&$ site $=3 \& i d=0>2.9 .2013$ (in Finnish).

Rantalainen S 2004. Luonnonsuojeselvitys YK0019. Ympäristökeskus Vantaa, C15: 2004.

Reilly J, Maggio P \& Karp S 2004. A model to predict impervious surface for regional and municipal land use planning purposes. Environmental Impact Assessment Review 24: 3, 363-382. http:// dx.doi.org/10.1016\%2Fj.eiar.2003.10.022.

RIL 124-2 (2004) 2004. Vesihuolto II, Helsinki. Suomen Rakennusinsinöörien Liitto (RIL). ISBN 951-758-438-5 (in Finnish).

Ruth O 2003. The effects of de-icing in Helsinki urban streams, Southern Finland. Water Science and Technology 48: 9, 33-43.

Schueler TR 1994. The importance of imperviousness. Watershed Protection Techniques 1: 3, 100-111.
Schueler TR 2000. Why stormwater matters. In Schueler TR \& Holland $\mathrm{H}$ (eds). The Practice of Watershed Protection, 25-30. Center for Watershed Protection, Ellicott City, MD.

Spencer A, Walker B, Arabi M, Frankenburger J \& Govindaraju RS 2009. Change in surface hydrology due to land use change in a Midwestern Watershed. Proceedings of World Environmental and Water Resources Congress 2009, Great Rivers 342, 5943-5952.

Suomen virallinen tilasto 2010. Kiinteistöjen hinnat. 4. vuosineljännes 2009. <www.stat.fi/til/kihi/2009/04/ kihi_2009_04_2010-03-12_tie_001.html> 2.9.2013 (in Finnish). Tilastokeskus, Helsinki.

Stone JB 2004. Paving over paradise: how land use regulations promote residential imperviousness. Landscape and Urban Planning 69: 1, 101-113. http://dx.doi.org/10.1016\%2Fj.landurbplan.2003.10.028.

Tuusulan kunta 2009. A new area called focus. $<$ http://sivustot.tuusula.fi/web/focus/tekstisivu. tmpl? numero $=17432576>2.9 .2013$.

United Nations 2012. World Urbanization prospects: The 2011 Revision, CD-ROM Edition. United Nations, Department of Economic and Social Affairs, Population Division.

U.S. Environmental Protection Agency 2006. Protecting water resources with higher density development. EPA publication 231-R-06-001.

Vantaan kaupunki 2008. 700400 Leinelä 1 Asemankaava. Vantaa, Kaupunkisuunnittelu, Asemakaavoitus (in Finnish).

Yu P-S, Wang Y-C \& Kuo C-C 2003. Effects of land-use change on runoff response in the ungauged TaChou basin, Taiwan. IAHS-AISH Publication 279, 162-170. 